\title{
ASUHAN KEBIDANAN PADA IBU HAMIL PRIMIGRAVIDA DENGAN KETIDAKNYAMANAN TRIMESTER III DI BPM SITI JULEHA TAHUN 2020
}

\author{
Intan Widya Sari ${ }^{1)}$ Rippo Riskiliani ${ }^{2)}$ \\ STIKes Hang Tuah Pekanbaru \\ Email : intanwidya@htp.ac.id
}

\begin{abstract}
Pregnancy is fertilization or fusion of spermatozoa and ovum and followed by bullying or implantation until the birth of the fetus, then the normal length of pregnancy is 280 days (40 weeks or 9 months 10 days) calculated from the first day of the last menstruation (Sarwono, P. 2014). This case study report aims to address the discomfort of third trimester primigravida pregnant women. The case method used is to provide comprehensive and continuous care through the SOAP documentation method. Midwifery Care In the third trimester of primigravida pregnant women performed at Ny. S, 22 years old with frequent complaints of BAK at night, upper and lower back pain and shortness of breath. After providing care from 11 September 2020 to 16 September 2020 with 3 visits, the results of the complaints felt by the mother began to decrease and disappear. As a place of health services, BPM Siti Julaeha should further increase the provision of health care in the form of information and education in an effort to overcome discomfort in third trimester pregnant women, especially primigravida mothers.
\end{abstract}

Keywords: Pregnant, Primigravida, Third Trimester Discomfort

\begin{abstract}
ABSTRAK
Kehamilan adalah fertilisasi atau penyatuan dari spermatozoa dan ovum dan dilanjutkan dengan nidasi atau implantasisampai lahirnya janin kemudian lamanya hamil normal adalah 280 hari (40 minggu atau 9 bulan 10 hari) dihitung dari hari pertama haid terakhir( Sarwono, P. 2014). Laporan studi kasus ini bertujuan untuk mengatasi rasa ketidaknyamanan pada ibu hamil primigravida Trimester III.Metode kasus yang digunakan adalah melakukan asuhan secara menyeluruh dan berkesinambungan melalui metode pendokumentasian SOAP. Asuhan Kebidanan Pada ibu hamil primigravida trimester III dilakukan pada Ny. S usia 22 tahun dengan keluhan sering BAK pada malam hari, sakit punggung atas dan bawah serta sesak nafas . Setelah di lakukan pemberian asuhan dari tanggal 11 September 2020 s/d 16 September 2020 dengan 3 kali kunjungan di dapat kan hasil keluhan yang di rasakan ibu mulai berkurang dan menghilang. Kemudian kami menyarankan saran untuk lebih baiknya kepada tempat pelayanan kesehatan BPM Siti Julaeha untuk lebih meningkatkan pemberian penkes berupa informasi dan edukasi dalam upaya mengatasi ketidaknyamanan pada ibu hamil trimester III terlebih pada ibu primigravida.
\end{abstract}

Kata Kunci : Kehamilan, Primigravida, Ketidaknyamanan Trimester III 
PENDAHULUAN

Kehamilan adalah fertilisasi atau penyatuan dari spermatozoa dan ovum dan dilanjutkan dengan nidasi atau implantasisampai lahirnya janin kemudian lamanya hamil normal adalah 280 hari (40 minggu atau 9 bulan 10 hari) dihitung dari hari pertama haid terakhir (Sarwono, P. 2014).

Pemeriksaan kehamilan minimal sebanyak 4 kali yaitu pada Trimester I ibu memeriksakan kehamilan minimal 1 kali pada 3 bulan pertama usia kehamilan, pada Trimester II ibu memeriksakan kehamilan minimal 1 kali pada 4-6 bulan pertama usia kehamilan, pada Trimester III ibu memeriksakan kehamilannya minimal 2 kali pada umur kehamilan 7-9 bulan (Muchtar, 2005).

Kapasitas paru terhadap udara inspirasi tetap sama seperti sebelum hamil atau mungkin berubah dengan berarti. Kecepatan pernapasan dan kapasitas vital tidak berubah. Volume tidal, volume ventilator permenit, dan ambilan oksigen meningkat. Karena bentuk dari rongga thorak berubah dan karena bernapas lebih cepat, sekitar $60 \%$ wanita hamil mengeluh sesak nafas (Ajeng ,N.Perubahan Adaptasi Fisiologi Ibu Hamil Trimester III . Yogyakarta: 2012)
Menurut National Sleep

Foundation (2007) dalam Rezaei (2015), perempuan hamil yang mengalami beberapa bentuk gangguan tidur mencapai $79 \%$. Sebanyak $72 \%$ dari ibu hamil akan mengalami frekuensi terbangun lebih sering pada malam hari. Umumnya kebutuhan tidur orang dewasa yakni selama 7-8 jam, namun untuk ibu hamil bisa mencapai 10 jam.Kualitas tidur yang baik akan menjaga kesehatan ibu selama hamil serta memberikan cukup energi saat persalinan

Cara mengatasi keluhan pada trimester 3 dengan keluhan sering buang air kecil adalah ibu hamil disarankan untuk tidak minum saat 2-3 jam sebelum tidur dan agar kebutuhan air pada ibu hamil tetap terpenuhi,sebaiknya minum lebih banyak pada siang hari. Sedangkan cara mengatasi keluhan sesak nafas pada pernafasan tidur dengan bantal yang tinggi, makan tidak terlalu banyak, konsultasi dengan dokter bila ada kelainan asma dan lain-lain. Cara mengatasi keluhan pada odema meningkatkan priode istirahat dan dengan berbaring posisi miring ke kiri, meninggikan kaki bila duduk, meningkatkan asupan protein, menganjurkan untuk minum 6-8 gelas cairan sehari untuk membantu diuresis natural (Hutahaean. Serri, 2013) 
Di BPM Siti Jualeha yang terletak di kota pekanbaru merupakan salah satu tempat layanan kesehatan yang memberikan pelayanan kesehatan pada ibu dan anak, BPM Siti Jualeha pada tahun 2019 menerima lebih dari 150 orang ibu bersalin selama 1 tahun. Di BPM Siti Jualeha saya melihat ibu hamil primigravida dengan keluhan ssering buang air kecil, sering BAK, sakit pungung atas dan bawah, sesak nafas, sulit tidur di malam hari, odema di kaki, nyeri pada pinggang, penglihatan kabur, pusing, pendarahaan, keputihan.

Jika ketidaknyamanan tidak diatasi maka akan terjadi ISK, Pada trimester ini presentase keluhan yang paling dirasakan ibu adalah sering kencing.Dari keluhan sering kencing ini, ibu hamil yang tidak melakukan penanganan dengan benar dapat terkena ISK. ISK telah diketahui berhubungan dengan kesudahankehamilan yang buruk, seperti persalinan preterm, pertumbuhan janin terhambat, bahkan janin lahir mati (stillbirth) (Kuswara, 2018).

\section{METODE PENERAPAN}

Metode yang penulis gunakan yaitu dengan cara melakukan asuhan kebidanan sesuai dengan prosedur yang baik dan benar pada pasien Ny "S" umur 27 tahun G1P0A0, dilaksanakan di BPM
Siti Juleha Pekanbaru. Penulis melakukan kunjungan ke rumah pasien, melakukan pendekatan diri dengan cara memperkenalkan diri, dan menanyakan apakah ada keluhan yang dirasakan pasien, setelah mengetahui keluhan ketidaknyamanan yang dialami ibu pada Trimester III. Dan kemudian penulis melakukan pemeriksaan ttv dan pemeriksaan fisik, dan dari hasil pemeriksaan yaitu ttv dan pemeriksaan fisik dalam batas normal. Penulis memberikan asuhan tentang konseling untuk mengatasi rasa ketidaknyaman yang dirasakan ibu pada trimester III. Asuhan ini dilakukan sebanyak 3 kali kunjungan untuk melihat apakah terdapat perubahan keluhan yang dirasakan oleh ibu.

\section{HASIL DAN PEMBAHASAN}

\section{A. HASIL}

Kunjungan pertama ini dilakukan pada tanggal 11 September 2020.

\section{Data Subjektif}

Ibu mengatakan sering BAK lebih dari 10 kali dalm semalam, sakit punggung atas dan bawah, terasa menyesak.

Ibu mengatakan hasil USG posisi bayinya letak kepala bagian terbawah 
KU baik, TD 110/60 mmHg, N, 80x/menit, Pr 22x/menit, S 36,6c Bb sebelum hamil 52 $\mathrm{kg}$, Bb sekarang $60 \mathrm{~kg}$, Lila $31 \mathrm{~cm}$ Tfu $30 \mathrm{~cm}$, presentasi kepala, DJJ 120x/menit TBBJ ( 30-13) x $155=2635$ gr.

Pemeriksaan palpasi :

тм Leopold 1 :TFU diatas simpisis ( $30 \mathrm{~cm}$ menurut M.c Donald). Teraba bulat keras dan melenting di perut bagian atas ibu yaitu kepala janin. Leopold 2 :Teraba panjang memapan diperut bagian kanan ibu yaitu punggung janin. Teraba tonjolan kecil di perut ibu bagian kiri ibu yaitu ekstremitas janin.

Leopold 3 :Terabakeras, bundar, dan melenting yaitu kepala janin.

3. Assasment

G1P0A0 Usia kehamilan 36 minggu, KU ibu baik,Janin tunggal, hidup, presentasi kepala, belum masuk PAP, DJJ 120x/menit dengan sering BAK, sakit pungugng atas dan bawah dan terasa menyesak.
4. Plan

Informasi dan edukasi :

1) Fisiologis kehamilan trimester III yang dirasakan pada ibu hamil

2) Konseling tentang ketidaknyamanan trimester III

3) Memberikan asuahan kebutuhan ibu hamil trimester III berupa nutrisi dan pola istirahat yaitu Nutrisi berupa omega 3 alami, kalsium, zat besi, vitamin a dan untuk pola istirahat malam 7-8 jam dan siang 1-2 jam

4) Melakukan Pendokumentasian

5) Jadwal kunjungan ulang

\section{B. PEMBAHASAN}

1. Data Subjektif

Data subjektif yang ditemukan yaitu ibu mengeluh dirinya sering BAK, sakit punggung atas dan bawah, kemudian dada terasa menyesak. Hal ini sesuai dengan teori (Aprilia, 2014) yang mengatakan bahwa pada ibu hamil yang memasuki trimester III mengalami ketidaknyamanan seperti : sering buang air kecil yang di alami. Menurut teori (Mafikasari dan Kartikasari, 
2015) Perubahan pada sistem muskuloskeletal yang terjadi selama kehamilan termasuk perubahan dalam postur, tulang belakang atau nyeri pinggang serta sebagai penguluran dari otot perut. Nyeri pinggang merupakan salah satu masa kehamilan menjelang bulan ke tujuh banyak wanita hamil mengalami nyeri pinggang bawah. Menurut teori (Pantiawati, 2010).

\section{Data Objektif}

Data Objektif dari asuhan yaitu keadaan umum ibu baik, TD : 110/60 mmHg, $\mathrm{N}$ : 80x/menit, $\mathrm{P}$ : $22 x /$ menit, $\mathrm{S}: 36,5 \mathrm{c}$ dan keadaan janin dalam batas normal. Yang ditemukan pada kunjungan pertama sampai kunjungan terakhir yaitu keadaan umum baik, kesadaran composmentis, dan tanda-tanda vital dalam batas normal, hasil pemeriksaan TFU berada dibawah proc.xypoideus, taksiran berat janin menurut Johnson Tausak ( $30-13) \times 155=2635$ gram dari hasil taksirat berat janin tersebut sesuai dengan teori (Khairoh, 2019)

3. Assasment

Berdasarkan penelitian yang telah di lakukan assesmen yang di dapatkan adalah G1P0A0 Usia kehamilan 37 minggu Janin tunggal, hidup, presentasi kepala, sudah masuk PAP, DJJ dalam batas normal.

4. Plan

Penulis memberikan asuhan dengan menjelaskan tentang cara menagatasi ketidak nyaman yang di rasakan oleh ibu seperti sering mengalami BAK yaitu disarankan untuk tidak minum saat 2-3 jam sebelum tidur dan agar kebutuhan air pada ibu hamil tetap terpenuhi, sebaiknya minum lebih banyak pada siang hari kemudian untuk mengatasi sakit punggung atas dan bawahdengan memberi kompres pada punggung selama kurang lebih 20 menit dan mengulanginya beberapa kali dalam sehari ketika sakit sampai dengan rasa sakit berkurang dan untuk mengatasi sesak nafas Tidur dengan bantal yang tinggi, Makan tidak terlalu banyak.

\section{KESIMPULAN}

Asuhan kebidanan pada ibu hamil primigravida dengan ketidaknyamanan trimester III di BPM Siti Juleha Pekanbaru dilaksanakan menggunakan pendekatan dengan pendokumentasi SOAP (subjektif, objektif, assessment, 
dan plan). Setelah mengumpulkan data secara keseluruhan dapat dibuat kesimpulan yaitu:

Setelah penulis mendapatkan persetujuan pasien bahwa akan dilakukan pemeriksaan, penulis dapat mengumpulkan data subjektif dan data objektif saat melakukan pengumpulkan data penulis tidak menemukan kesulitan karena pasien bersedia kerja sama. Setelah dilakukan pemberian asuhan secara menyeluruh dan berkesinambungan melalui metode pendokumentasian SOAP pada ibu hamil primigravida yang mengalami ketidaknyamanan Trimester III didapat kan hasil keluhan yang di rasakan perlahan berkurang dan menghilang.

\section{DAFTAR PUSTAKA}

Andriyani, A. (2015). Asuhan Kebidanan Komprehensif. Jakarta : Salemba Medika.

Hutahean, S. (2013). Perawatan Antenatal. Jakarta: Salemba Medika. IA, L. (2018).

Kamariyah, N., Y, A., \& Dkk. Konsep Dasar Kehamilan Trimester 3. (2014).
Mariyam Ulfa Sukorini. Ilmu Kebidanan, Penyakit Kandungan dan KB. Jakarta: EGC. (2017).

Marwiyah, N., \& Sufi, F. Hubungan Gangguan Kenyamanan Fisik Dan Penyakit Dengan Kualitas Tidur Ibu Hamil Trimester III. The Indonesian Journal of Public Health, 12(1), 1-12.. (2018).

Prawirohardjo, S . Pengaruh Senam Hamil Terhadap Kualitas Tidur Ibu Hamil Trimster II dan III di Kelurahan Margaluyu Wilayah Kerja Puskesmas Kasemen. Falentehan Health Journal, 3, 123-128. (2014).

Pantiawati, D. Ilmu Kebidanan (4th ed.). Jakarta: Jakarta Bina Pustaka. (2010).

Mafikasari, A., \& Kartikasari, R. A . Asuhan Kebidanan I. Jakarta : Nuha Medika. (2015).

Wahyuni, S. Posisi Tidur Dengan Kejadian Back Pain (Nyeri Punggung) Pada Ibu Hamil Trimester III. 07 (02), 26. (2010). Lintang Pustaka Sulistyawati, Senam Hamil; Menyamankan

Kehamilan, Mempermudah Persalinan. Yogyakarta: (2011). 